\title{
Experimental Study of Wickless Heat Pipe with Flat Evaporator for Used in Cooling of Electronic Components
}

\author{
Samah Ihsan Adnan ${ }^{1}$ Aouf Abdulrahman Ahmad ${ }^{2}$ Adnan Abdulamar Abdulrasool ${ }^{3}$
}

1) Mechanical Engineering Department, Engineering College,University of AlMustansiriyah, Baghdad, Iarq.

${ }^{1} \underline{\text { sa146842@gmail.com }}$

2) Mechanical Engineering Department, Engineering College,University of AlMustansiriyah, Baghdad, Iarq.

2 aoufaltabbakh72@gmail.com

${ }^{3)}$ Mechanical Engineering Department, Engineering College, University of Al-Mustansiriyah, Baghdad, Iarq.

3 adnan ameer54@yahoo.com

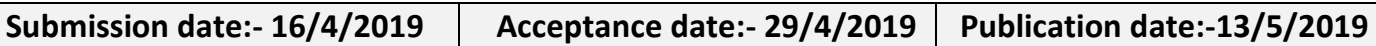

\begin{abstract}
In this paper, systematic experimental investigations were carried out for a wickless heat pipe with flat evaporator having dimensions $(100 \times 100 \times 30) \mathrm{mm}$. Flat-square electrical element was used to simulate the heat source of electronic part with dimensions of $(100 \times 100) \mathrm{mm}$. The aim of this paper presents the effect of fill ratio and cooling water mass flow rate on thermal performance of a wickless heat pipe. Experiments were performed to evaluate performance of wickless heat pipe for range of input power from $10 \mathrm{~W}$ to $100 \mathrm{~W}$. The fill ratios used in the present work were $15 \%, 25 \% 50 \%$ and $85 \%$. The cooling water mass flow rate was also changed from $0.0083 \mathrm{~kg} / \mathrm{s}$ to $0.033 \mathrm{~kg} / \mathrm{s}$. Experimental results showed that the maximum value of wall evaporator temperature was $115^{\circ} \mathrm{C}$ at input power of $100 \mathrm{~W}$ and a fill ratio of $15 \%$. Results also showed that the maximum value of the total resistance was $0.8^{\circ} \mathrm{C} / \mathrm{W}$.
\end{abstract}

Keywords: Wickless Heat Pipe, Input power, Fill Ratio, Saturation Temperature.

Symbol List:

\begin{tabular}{|c|c|c|}
\hline Symbol & The meaning of the symbol & Measuring unit \\
\hline $\mathrm{A}$ & Area & $\left(\mathrm{m}^{2}\right)$ \\
\hline $\mathrm{Cp}$ & Specific Heat & $\left(\mathrm{Kj} / \mathrm{kg} .{ }^{\circ} \mathrm{C}\right)$ \\
\hline $\mathrm{h}$ & Heat transfer coefficient & $\left(\mathrm{W} / \mathrm{m}^{2} .{ }^{\circ} \mathrm{C}\right)$ \\
\hline $\mathrm{h}$ & Latent heat of evaporation & $(\mathrm{j} / \mathrm{kg})$ \\
\hline $\mathrm{I}$ & Current & $(\mathrm{A})$ \\
\hline $\mathrm{R}$ & Thermal resistance & $\left({ }^{\circ} \mathrm{C} / \mathrm{W}\right)$ \\
\hline $\mathrm{Q}$ & Heat input & $($ Watt $)$ \\
\hline $\mathrm{T}$ & Temperature & $\left({ }^{\circ} \mathrm{C}\right)$ \\
\hline$m$ & Mass flow rate & $(\mathrm{Kg} / \mathrm{sec})$ \\
\hline $\mathrm{V}$ & Voltage & $(\mathrm{Volt})$ \\
\hline
\end{tabular}




\section{List of Subscripts:}

\begin{tabular}{|c|c|}
\hline Symbol & Definition \\
\hline 1 & Inlet \\
\hline Cond & Condenser \\
\hline e & Evaporation \\
\hline Evap & Evaporator \\
in & Input \\
\hline sat & Saturation \\
\hline v & Vapor \\
\hline w & Water \\
\hline W & Wall \\
\hline
\end{tabular}

\section{Introduction}

Heat pipes are two-phase devices transfer heat from the source to the sink by working fluid. The advantage of using the wickless heat pipe is its need for small space and temperature change. In addition, the easy of design, high rate of heat transfer, one-way thermal transfer, low weight, low cost of maintenance, etc. make this device more difficult. Wickless heat pipe heat transfer contains some operations and operating mechanisms that need to be considered before further discusses wickless heat pipe technologies and applications. [1]

Figure 1 shows a schematic of straight heat pipe (wickless), which consists of an evaporator, a condenser and single connecting pipe. The working fluid heating is in the bottom part of pipe (evaporator) and becomes vapor. The vapor moves through the middle part of pipe (adiabatic part) to top part (condenser) of the pipe. Where the vapor condenses in the condenser back to liquid and return to the evaporator by the gravity force. [2]

Some previous research may be presented this type of heat pipe: Rafal and rzeejczyk, 2018 [3] experimental studied investigation of the thermal performance of a wickless heat pipe. It is study effect of different parameters on performance of straight heat pipe were different working fluid and fill ratio. The results showed that the best the thermal resistance decreases with increase input power and thermal rises with rise of fill ratio

Adel et al., [4] worked numerical and experimental investigation of the thermo-syphon performance in (HVAC) system. They studied the effect of fill ratio and working fluid changed on the performance of thermo-syphon and used FORTRAN program in the theoretical model for this work. The results shown that the heat transfer capacity was related to the use of acetone and water as compared with other fluids under same range of operating temperature from $35^{\circ} \mathrm{C}$ to $50^{\circ} \mathrm{C}$.

Ahmad et al., [5] studied the effect of fill ratio and inclination angle on thermal performance of thermosyphon heat pipe by using a new CFD simulation. The results showed that the best fill ratio and inclination angle were $65 \%$ and $90^{\circ}$.

Marc et al., [6] experimentally and numerically studied a counter-current two-phase thermosyphon with cascading pools. They used a numerical model and control volume approach developed to predict and validate the experimental results of the innovative design.

Fadhl et al., [7] numerical studied of the two-phase closed thermo-syphon by using a CFD simulation. They used R134a and R404a as working fluid. They found that the thermal characteristics of both fluids within the thermo-syphon vary significantly as compared with water.

Abdullahi, [8] experimentally and numerically investigated the effect of cooling flow rate and input energy on the thermal performance of thermo-syphon heat pipe. It is using CFD analysis in numerical work. The results showed that the heat transfer characteristics of a two-phase closed thermosyphon increasing with inclination angle and input power increase.

Anjankar and R. yarasu., [9] studied experimental analysis of effect condenser length on the thermal performance of thermo-syphon. In this paper, investigated experimentally the thermal performance of straight two-phase closed thermo-syphon changed flow rate and heat input to evaporator with different condenser length. They found that the flow rate of $0.0027 \mathrm{~kg} / \mathrm{sec}$ and input power $500 \mathrm{~W}$ with the condenser length of $450 \mathrm{~mm}$ produce the higher thermal performance of thermo-syphon. 
Shoumng et al., [10] investigate experimental of the thermal modeling of thermo-syphon for (CPU) cooling. The experimental setup of thermo-syphon consists of three sections: evaporator, adiabatic and condenser. the results show that the thermal input increases the effectiveness and thermal resistance decreases.

Jiao et al., [11] studied the effect of fill ratio on the steady-state heat transfer performance of a vertical Two-Phase Closed Thermo-syphon (TPCT). They used in experimental work two dissimilar geometries of the TPCT and nitrogen as working fluid. They concluded the range of fill ratio, which can keep a TPCT steady and effective, is future based on investigation and comparison.

Hussein et al., [12] studied the effect of inclination angle on the performance of copper thermosyphon with different diameter $(7.5,11.1$ and 25.4$) \mathrm{mm}$. They used water, R-22, R-123, R-134a and ethanol as working fluid. They found that the best inclination angle is between $40^{\circ}$ and $70^{\circ}$ for water.

The current work endeavors to experimentally study type of wickless heat pipe. The study seeks the effect of fill ratio and cooling water flow rate on the thermal performance of straight heat pipe in the range of heat fluxes that is mostly used in electronic components and small electrical parts.

\section{Experimental setup}

The straight heat pipe setup used in the experimental work consists of an evaporator, a condenser and connecting single pipe as show in Figure 2. The connecting pipe acts as a riser to carry the rising vapor as well as downcomer to return the condensate to evaporator. The wickless heat pipe is made of copper to resist corrosion by water and it has high thermal conductivity. The evaporator is placed on the bottom part and the condenser at the top part of the straight heat pipe to enable gravity effect. The total length of wickless heat pipe $350 \mathrm{~mm}$. Evaporator made of a copper alloy box of dimensions (100x100x30) mm. The input energy is provided through an electric heater. The heater plate is made of aluminum alloy length $100 \mathrm{~mm}$ and $100 \mathrm{~mm}$ width. The heater tightly attached to the lower side of the evaporator tightly isolated on the other side to confirm that all the power source is directed to the evaporator. Condenser section made of a cylindrical pipe copper of $150 \mathrm{~mm}$ length and $15 \mathrm{~mm}$ diameter. The condenser is covered by a water jacket of the same dimension of it.

The components of the straight heat pipe are insulated by using polyurethane (foamy) to reduce the losses of heat to the atmosphere. Figure 3 shows the photo of the straight heat pipe test rig under consideration.

\section{Measuring Devices}

In this work, several kinds of measurement devices were used. An AC electric energy source of $220 \mathrm{~V}$ provides to the heater. The power provided by the heater can range from 0 to 250 watts. Ten data points for measurements temperature of the straight heat pipe by using calibrated K-kind thermocouples. Thermocouples (No.1-5) are involved with the outside surface of the straight heat pipe to measure wall temperature of evaporator. The thermocouple (no.6) measures the temperature of vapor outlet from the evaporator. Thermocouple (no.7) measures the temperature of vapor inlet the condenser. Two thermocouple (no.8-9) are used to measure the inlet and outlet temperature of cooling water jacket. The ambient temperature measures by using thermocouple (no.10). The temperature is monitored and record by used data logger kind (BTM-4208SD) which contains 12 Channels. Figure 4 shows a view of the positions of the thermocouples about straight heat pipe. The vacuum pressure and saturation pressure are measured by using two devices. One device is a digital pressure meter kind (Lotron PS-9302) and other device is a pressure gage.

\section{Experimental Procedure}

Before starting the experimental tests, the straight heat pipe is evacuated by a vacuum compressor though all valves are closed. The system is locked after the vacuum process with a vacuum pressure of $10 \mathrm{kpa}$.

The straight heat pipe is then filled with distilled water as working liquid. Distilled water is full via the liquid side column. The column valve is then unlocked to allow the water to cross the emptied space of the heat pipe. The filling valve is closed when the required quantity of the water indicated through the level evaluation is reached. 
Heating of the straight heat pipe is then initiated by opening the voltage additive and the source of power on the control plate. The data acquirement system is opened and the temperature readings are shown.

Steady state situation is attained within 15 to 30 minutes after the startup, the situation that all the readings practically unchanged. The experimental readings are then started and the data are verified for the next three hours.

\section{Data Analysis}

The input power $Q_{\text {in }}$ is estimated as voltage $\mathrm{V}$, times current I :-

$$
Q_{\text {in }}=\mathrm{V} \mathrm{I}
$$

The thermal resistance of evaporator $R_{\text {evap }}$ is estimated as the rate of temperature variation to the input power $Q_{\text {in }}[13]$ :

$$
R_{\text {evap }}=\frac{T_{w}-T_{\text {sat }}}{Q_{\text {in }}}
$$

The thermal resistance of condenser $R_{\text {cond }}$ is valued by the following equation:

$$
R_{\text {cond }}=\frac{T_{V}-T_{\text {in }}}{Q_{\text {cond }}}
$$

The rate heat transfer of condensation $Q_{c o n d}$ is evacuated from the cooling water temperature increase through the water jacket as follows:

$$
\begin{aligned}
& Q_{\text {cond }}=m_{w} c p_{w}\left(T_{\text {out }}-T_{\text {in }}\right) \\
& R_{\text {total }}=R_{\text {evap }}+R_{\text {cond }}
\end{aligned}
$$

The heat transfer coefficient of evaporation is defined by the following equation [14] $\square$

$$
h_{e}=\frac{A Q_{\text {in }}}{T_{w}-T_{s a t}}
$$

\section{Results}

The filling ratio is a very main issue to impact the thermal performance of straight heat pipe. Figure (5) shows the variation of measurement average wall of evaporator temperature of input power ranging from $10 \mathrm{~W}$ to $100 \mathrm{~W}$ at a stage of $10 \mathrm{~W}$ when the fill ratios $15 \%, 25 \%, 50 \%$ and $85 \%$. It can be understood from the figure that the average wall temperature increases with increase input power for each fill ratios. Increasing fill rate inclines to lessen the wall temperature since of the enhanced evaporation ratio.

Figure (6) shows variation of measurement wall, inlet, outlet evaporator and saturation temperatures with evaporator input power when a fill ratio $50 \%$.

Figure (7) shows variation of measured the saturation pressure of SHP with input power evaporator for each fill ratios. The figure shown that the saturation pressure increases with input power increase. The pressure rate increases when the fill ratio increase because of the smaller space that happen when the fill ratio rises.

Figures (8) and (9) show the experimental difference of measurement evaporator and condenser resistance with evaporator input power for four fill ratios. The figures shown that the resistances of evaporator and condenser are decreased with input power increasing, but the slope become more 
moderate with the increase in the input power and fill ratios. This refers to type of chocking in the straight heat pipe that prevents further evaporation.

Figure (10) shows the variation of measurement total resistance of straight heat pipe with input power for each fill ratios. The figure have been shown that the maximum value of the total resistance was $0.82\left({ }^{\circ} \mathrm{C} / \mathrm{W}\right)$ at input power $100 \mathrm{~W}$ when a fill ratio $85 \%$.

The vapor generated in the evaporator takes its heat from an electric heater attached to the bottom side of the evaporator. The amount of vapor depends strongly on the amount of the working fluid exposed to heat. The condensate flows back to the evaporator by gravity effect. So, the heat pipe can continuously transport the latent heat of vaporization from the evaporator to the condenser sections.

Figure (11) shows the difference of measurement evaporation heat transfer coefficient with input power of evaporator for each fill ratios. It can be understood from the figure that the coefficient heat transfer of evaporation increases with evaporator input power for each fill ratios. This trend is physically correct because when the supplied power is increased, the heat transfer to the evaporator increases. The maximum value of evaporation heat transfer coefficient in straight heat pipe was $\left(830 \mathrm{w} / \mathrm{m}^{2} .{ }^{\circ} \mathrm{C}\right)$ when the power input of $100 \mathrm{~W}$ and a fill ratio of $50 \%$.

The cooling rate of Straight Heat Pipe (SHP) is changed by changing the cooling water conditions in the condenser jacket. Figure (12) shows experimental variation of measured total resistance for range of cooling water mass flow rates starting from $0.0083 \mathrm{~kg} / \mathrm{s}$ to $0.033 \mathrm{~kg} / \mathrm{s}$ at a step of $0.00833 \mathrm{~kg} / \mathrm{s}$ at input power $50 \mathrm{~W}$ for fill ratios $15 \%, 25 \%, 50 \%$ and $85 \%$. The effect of changing the cooling water flow rates on the total thermal resistances of SHP is tested at the same conditions. The figure has been shown that the total resistance increases with the increase in the cooling water mass flow rate. The reason behind this trend is that the evaporator inlet temperature is proportional to cooling water mass flow rate. This makes the evaporator consumes more power to evaporate the same amount of working fluid. The minimum value of total resistance at cooling water flow mass rate of $0.016 \mathrm{~kg} / \mathrm{s}$.

\section{Conclusions}

The present study experimentally investigated the thermal performance of a straight heat pipe. The focus was on the effect of fill ratio and cooling water mass flow rate on the evaporator wall temperature and thermal resistances around the SHP.

1. They found that the average wall temperature in the evaporator always increases with power. The maximum value of wall temperature was $115^{\circ} \mathrm{C}$ in Straight Heat Pipe (SHP) when input power of $100 \mathrm{~W}$ and a fill ratio of $50 \%$

2. Both evaporator and condenser resistances decrease with increasing input power. The minimum value of evaporator resistance was $0.17{ }^{\circ} \mathrm{C} / \mathrm{W}$ at an input power of $70 \mathrm{~W}$ and a fill ratio of $50 \%$, while the condenser resistance was $0.33\left({ }^{\circ} \mathrm{C} / \mathrm{W}\right)$ at the same operating conditions of SHP.

3. The total resistance increases with an increase in the cooling water mass flow rate. The optimum cooling water mass flow rate was $0.016 \mathrm{~kg} / \mathrm{s}$.

\section{CONFLICT OF INTERESTS.}

- There are no conflicts of interest.

\section{Reference:}

[1] D. Japikse," Advances in thermosyphon technology ," In Advances in Heat Transfer," edited by T.F, Irvine and J.P.Harthen, Vol. 99, PP.1-111, 1973.

[2] Shabgard H. Allen M,"Heat pipe heat exchangers and heat sinks: opportunities, challenges, applications, analysis, and state of the art," Int. J. Heat Mass Transfer," Vol.89, pp.139-158, 2016.

[3] Rafal Andrzejczyk," expermintal investigation of the thermal performance of a wickless heat pipe operating with different fluids: water, ethanol, and SE36. Anglysis of influences of instability processes at working operation parameters", energies, Vol.11,PP.70-230, 2018.

[4] Adel. A. S. Jalal.," Experimental and Numerical investigation of Thermosyphone Performance in HVAC system applications," Heat Mass Transfer", vol. 10, pp. 16-26, 2016. 
[5] Ahmed A. Alamnar, Raya K., Saad M.," Numerical investigation of effect of fill ratio and inclination angle on a thermosiphon heat pipe thermal performance," Applied Thermal Engineering, Vol.108, pp.1055-1065, 2016.

[6] Marc S, Wessel W, Gert R, "Numerical and experimental investigation of a counter-current twophase thermosyphon with cascading pools," Applied Thermal Engineering, Vol.99, pp.133-146, 2016.

[7] B. Fadhl. Wrobel Lc, Jouhara H., a CFD model of Two-Phase due Thermosyphon charged with R134a and R404a," Applied Thermal Engineering, Vol.78, pp. 482-490, 2015.

[8] B. Abdullahi," Development and optimization of heat pipe based compound parabolic collector," Thesis submitted to University of Birmingham, 2015.

[9] P. G. Anjankar, R. Yarasu. ," Experimental Analysis of Condenser Length Effect on the Performance of Thermosyphon, "Int. J. Emerging Technology and Advanced Engineering," Vol. 2, pp.2250-2490, 2012.

[10] A. Shanmnga S, Anirdh B. ,"Thermal Modeling of Thermosyphon Integrated Heat Sink for CPU Cooling," Journal of Electronic Cooling and Thermal Control, Vol.1, pp.15-21, 2011.

[11] B. Jiao et al.," Investigation on the effect of filling ratio on the steady-state heat transfer performance of a vertical two-phase closed thermosiphon," Applied Thermal Engineering, Vol. 28, no.11-12,pp. 1417-1426, , 2008.

[12] Hussein, H. M. S., Mohamad, M. A. \& El-Asfouri, A. S,"Theoretical analysis of laminar-film condensation heat transfer inside inclined wickless heat pipes flat-plate solar collector,"Renewable Energy, Vol. 23, pp. 525-535, 2001

[13] Y.J. Chen, P.Y. Wang, Z.-H. Liu, and Y.-Y. Li, "Heat transfer characteristics of a new type of copper wire-bonded flat heat pipe using nano fluids, "Heat Mass Transfer, Vol. 67, pp. 548-559, 2013.

[14] A. B. Solomon, R. Roshan, W. Vincent, V. K. Karthikeyan, and L. G. Asirvatham,"Heat transfer performance of an anodized two-phase closed thermosyphon with refrigerant as working fluid, "Heat Mass Transfer., vol. 82, pp. 521-529, 2015. 


\title{
دراسة عملية أنبوب حراري بلون حشوة ذات المبخر مسطح يستخدم في تبريد المكونات الإكترونية
}

\author{
سماح احسان عدنان عوف عبدالرحمن احمدعلعبنان عبدالامير عبدالرسول \\ قسم الهندسة المبكانيكية، كلية الهندسة، الجامعة المستنصرية، بغداد، العراق
}

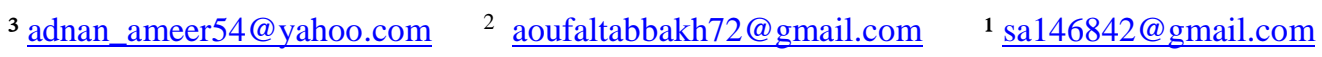

الخلاصة

في هذا البحث، نم اجراء التحقيقات التجريية على الانبوب الحراري بدون حشوة ذات المبخر المسطح الذي ابعادة

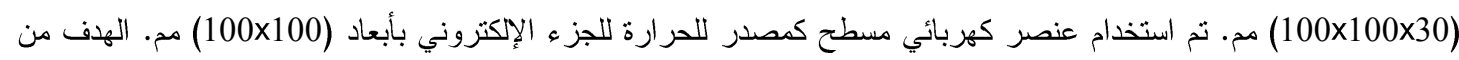

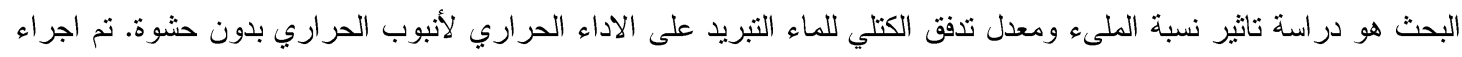

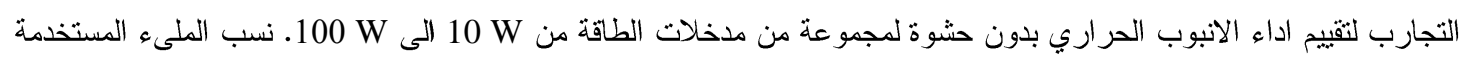

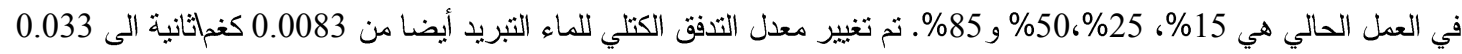
كغاثانية. أظهرت النتائج ايضا ان اعظم قيمة للمقاومة الكلية كانت مساوية كلمات الداله: الانبوب الحر اري بدون حشوة، مدخلات الطاقة، نسبة الملىء، درجة حرارة التثبع. 


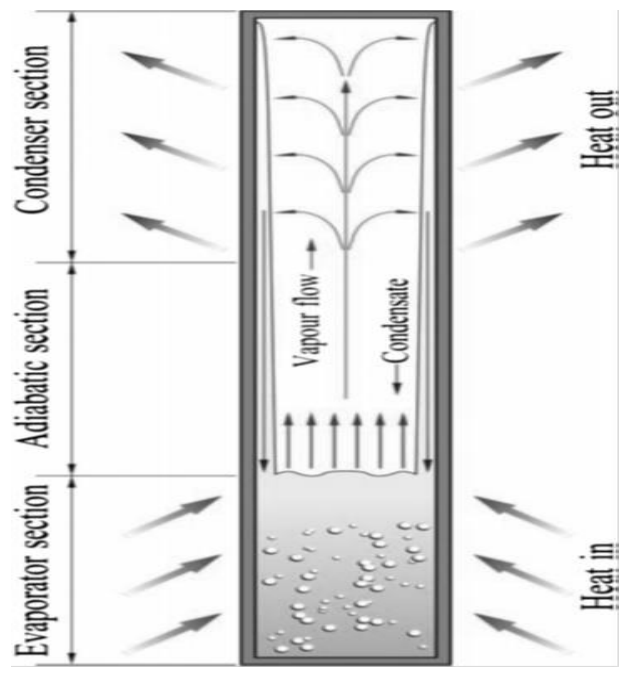

Figure (1) Schematic diagram of Straight Heat Pipe.

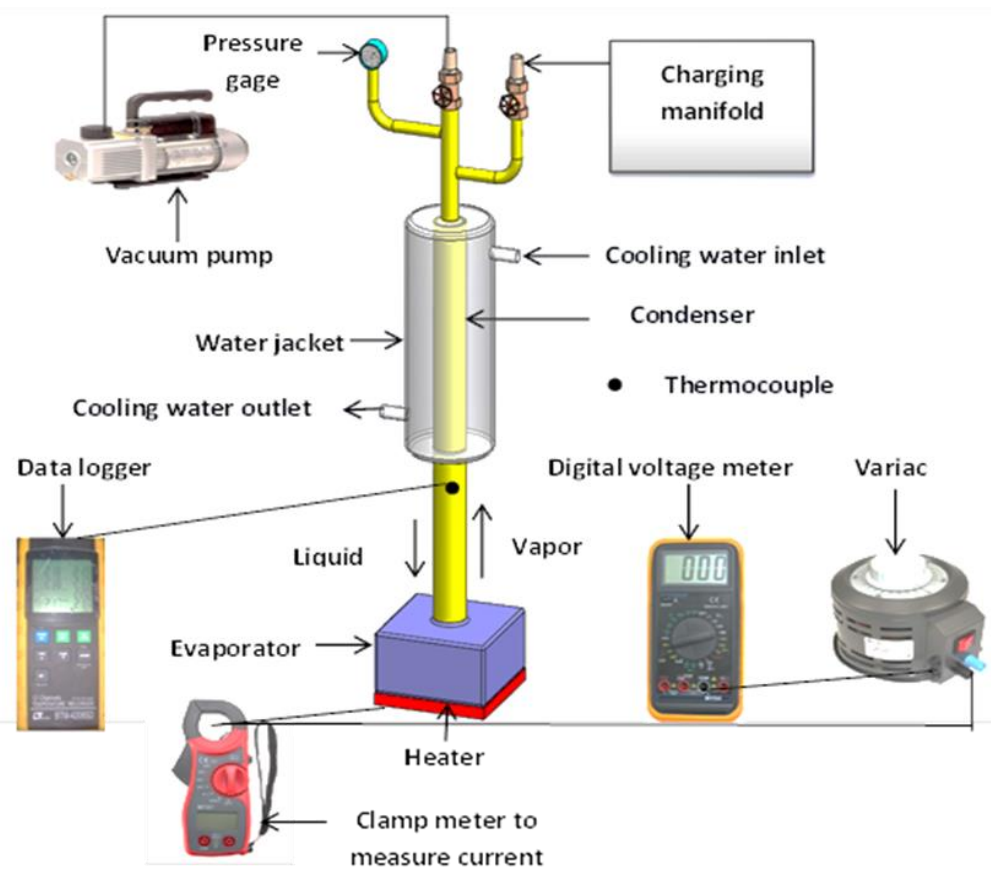

Figure (2) Schematic diagram of the experimental setup of the straight heat pipe. 


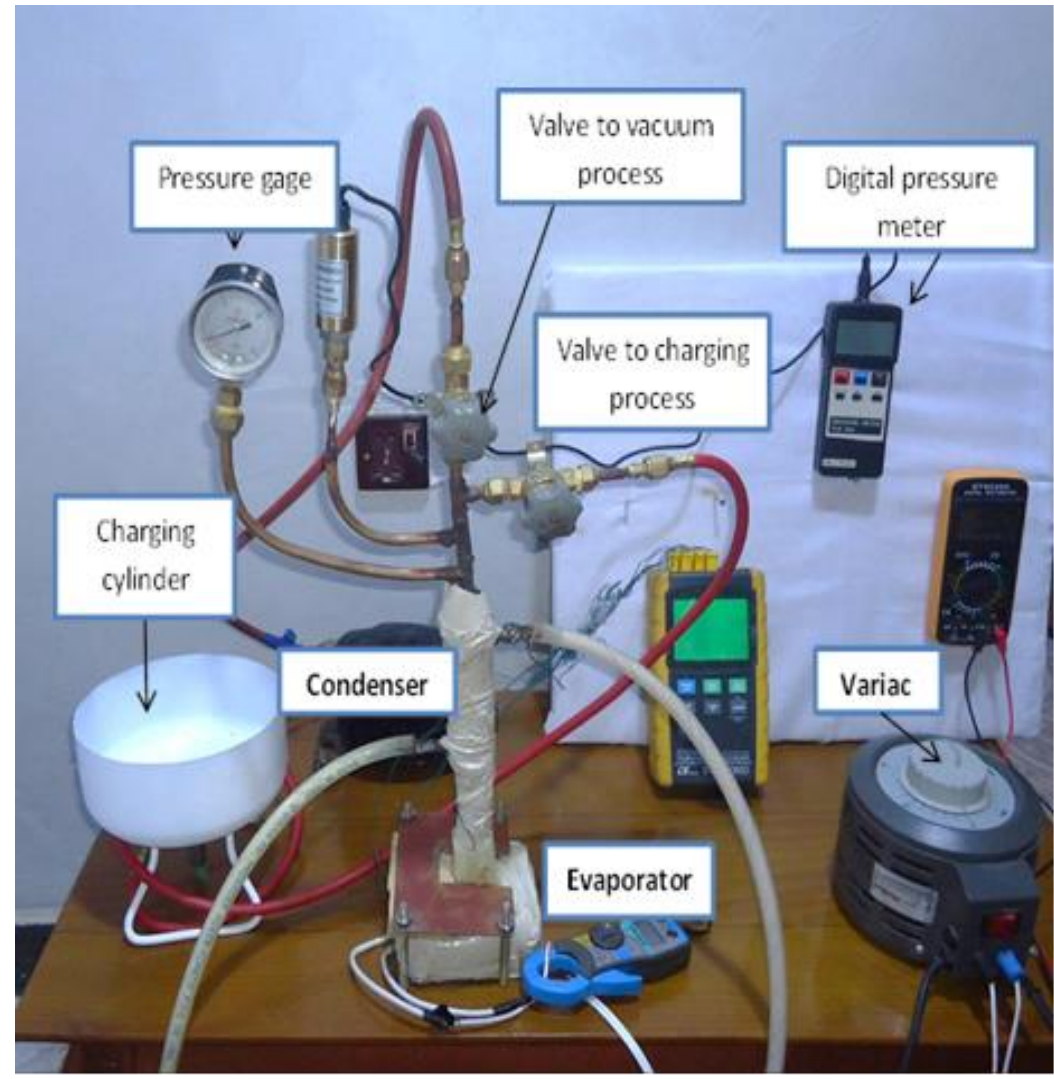

Figure (3) Photo of the experimental setup of straight heat pipe.

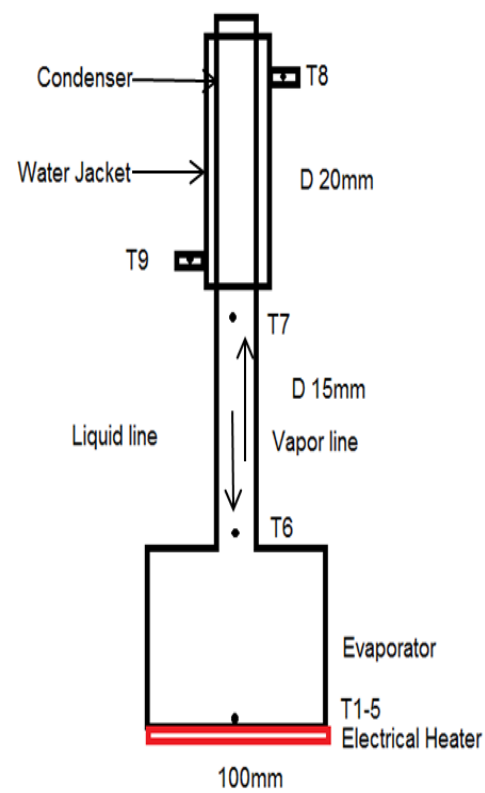

Figure(4) Schematic views of the locations of the thermocouples in the straight heat pipe. 


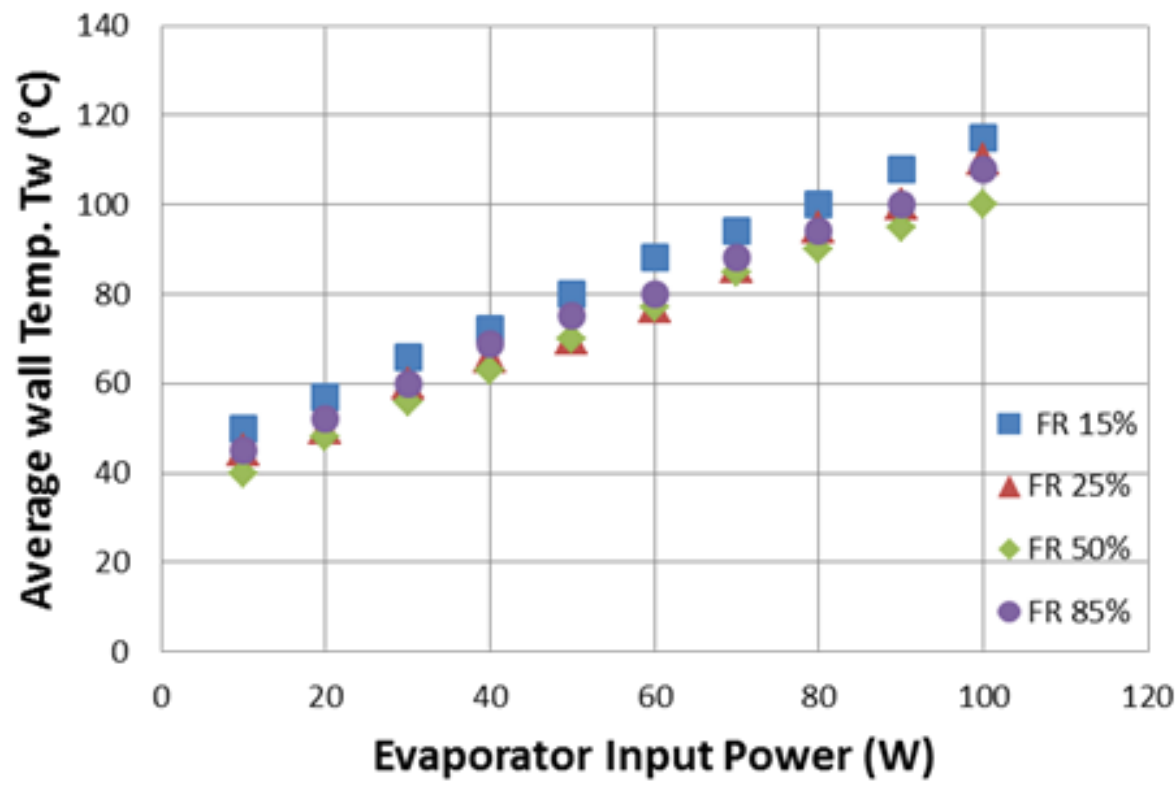

Figure (5) Experimental variation of measured average wall temperature in evaporator of SHP with Evaporator input power for four fill ratios.

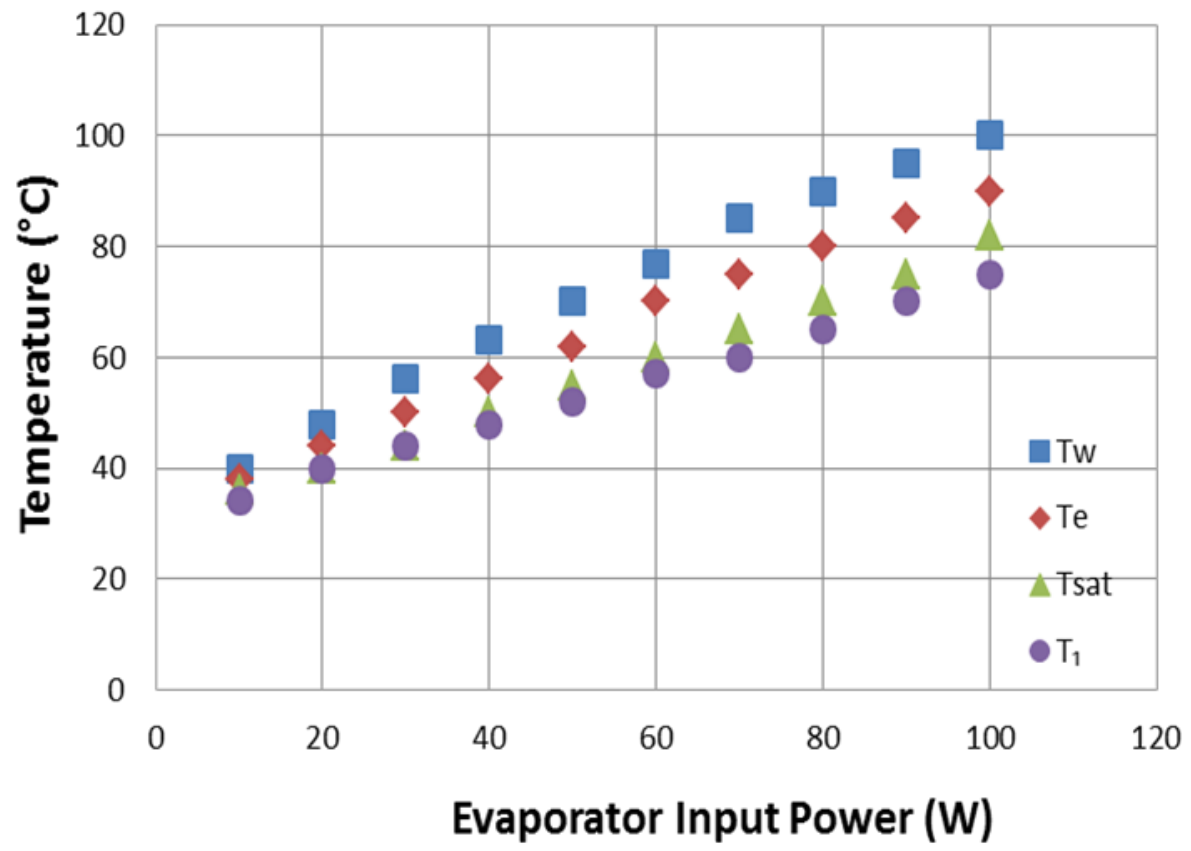

Figure (6) Experimental variation of measured wall ( $\mathrm{Tw}$ ), (inlet/out) evaporator $\left(\mathrm{Te}, \mathrm{T}_{\mathbf{1}}\right)$ and (Tsat) saturation temperature of SHP with evaporator input power at a fill ratio of $50 \%$. 


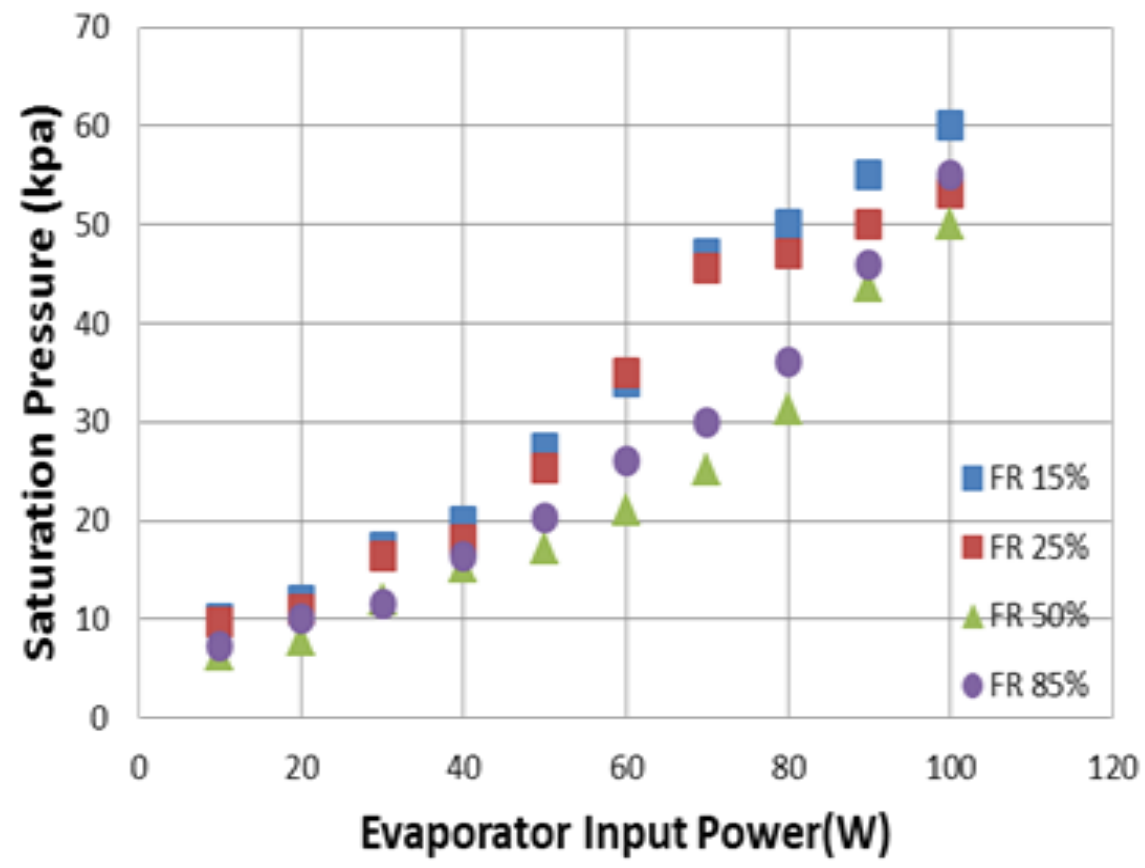

Figure (7) Experimental variation of measurement saturation pressure of SHP with input power of evaporator for four fill ratios.

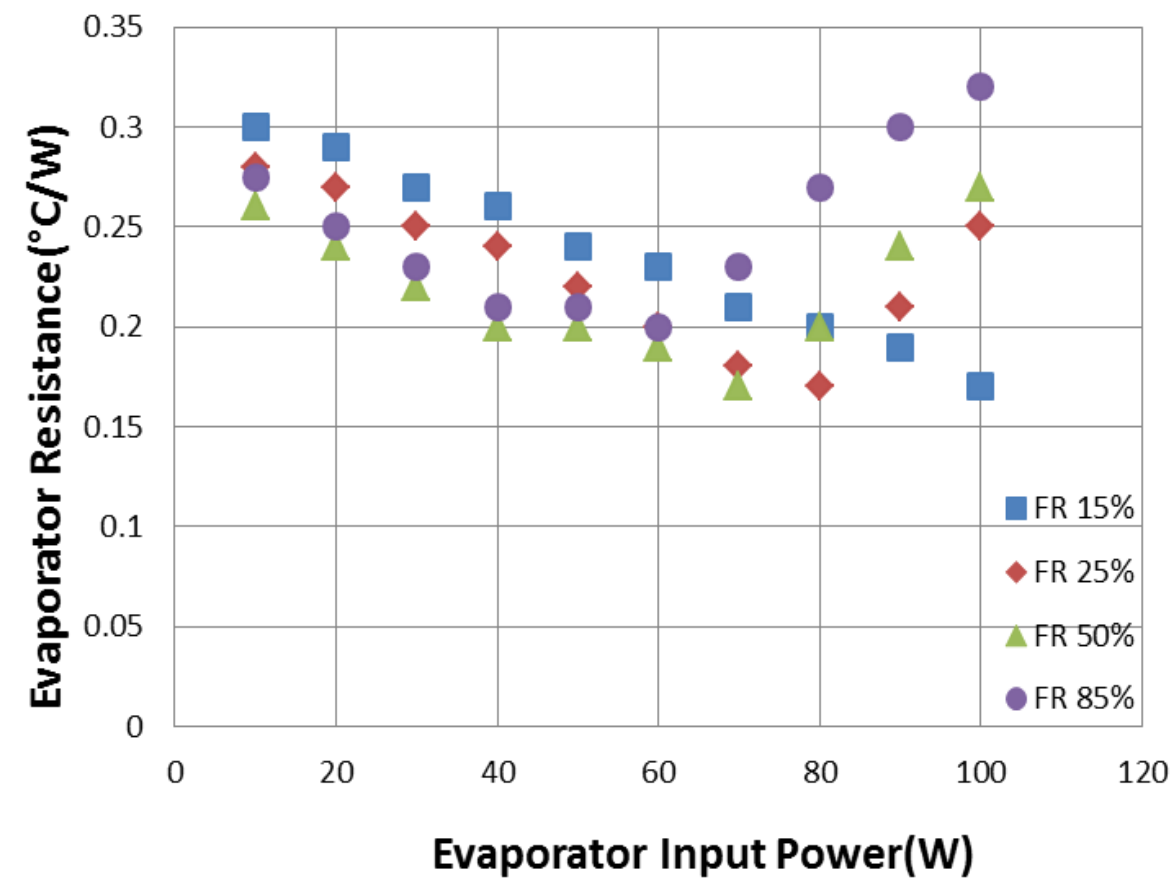

Figure (8) Experimental variations of measured resistance evaporator of SHP with evaporator inlet power for four fill ratios. 


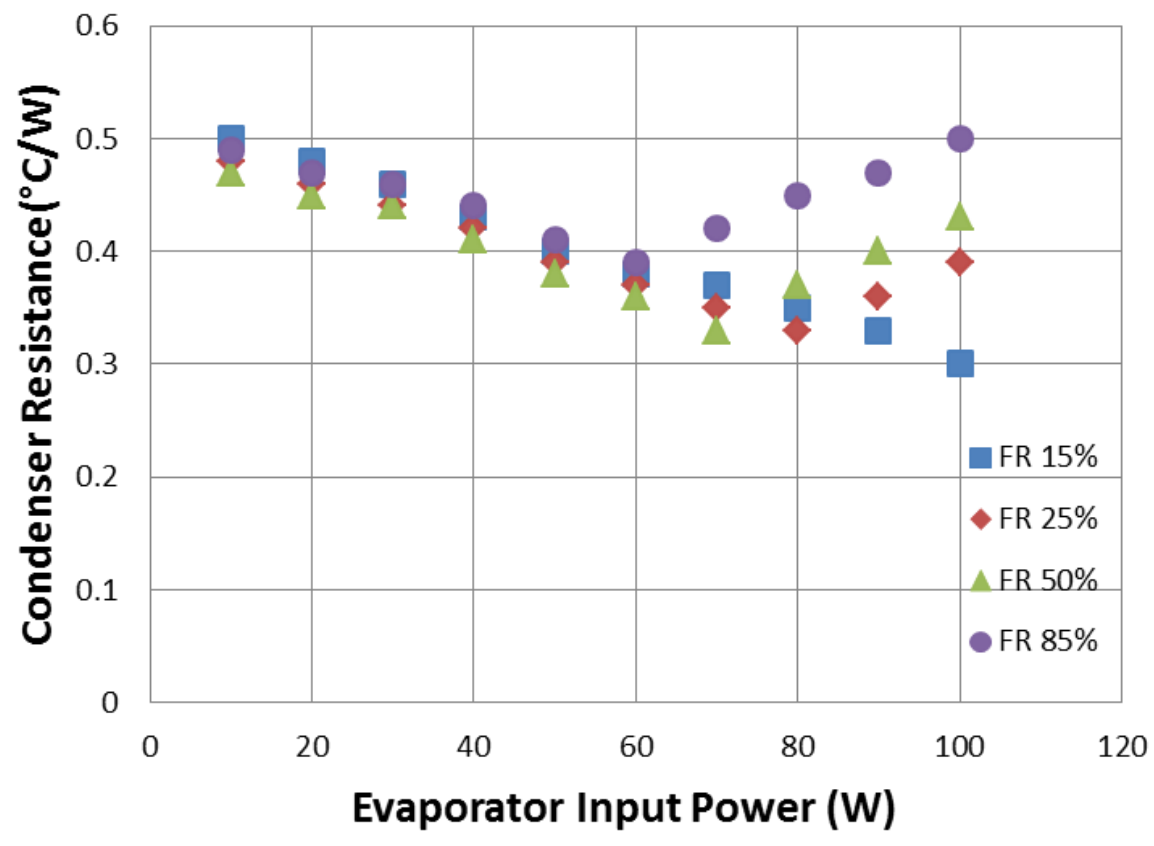

Figure (9) Experimental variations of measured condenser resistance of SHP with evaporator inlet power for four fill ratios.

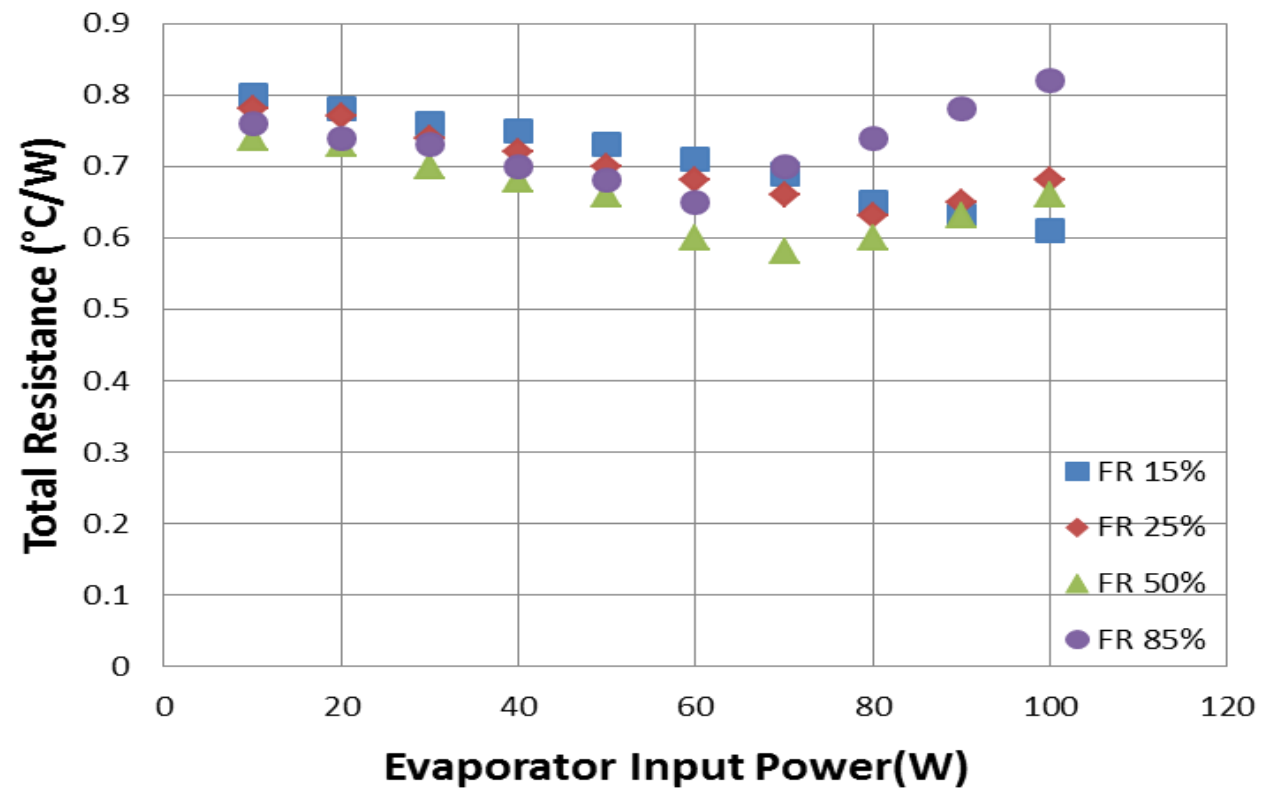

Figure (10) Experimental variations of measured total resistance of SHP with evaporator inlet power for four fill ratios. 
Journal of University of Babylon for Engineering Sciences, Vol. (27), No. (2): 2019.

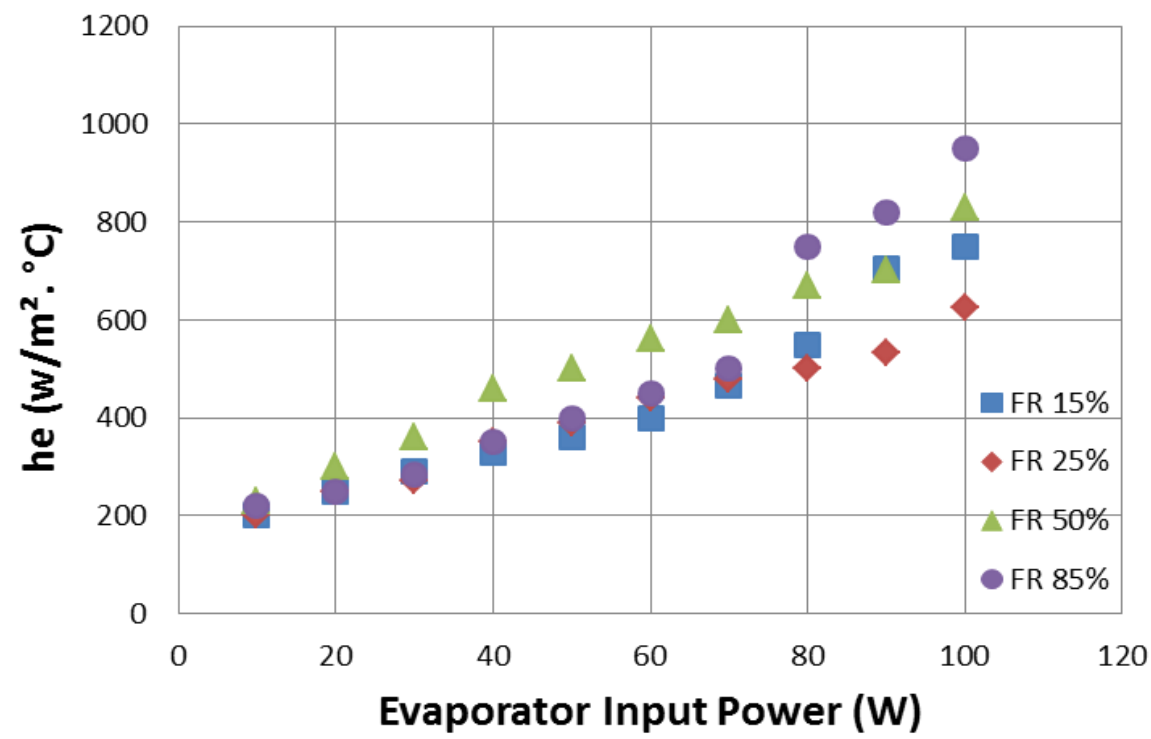

Figure (11) Experimental variation of measured evaporation heat transfer coefficient of SHP with evaporator input power for four fill ratios.

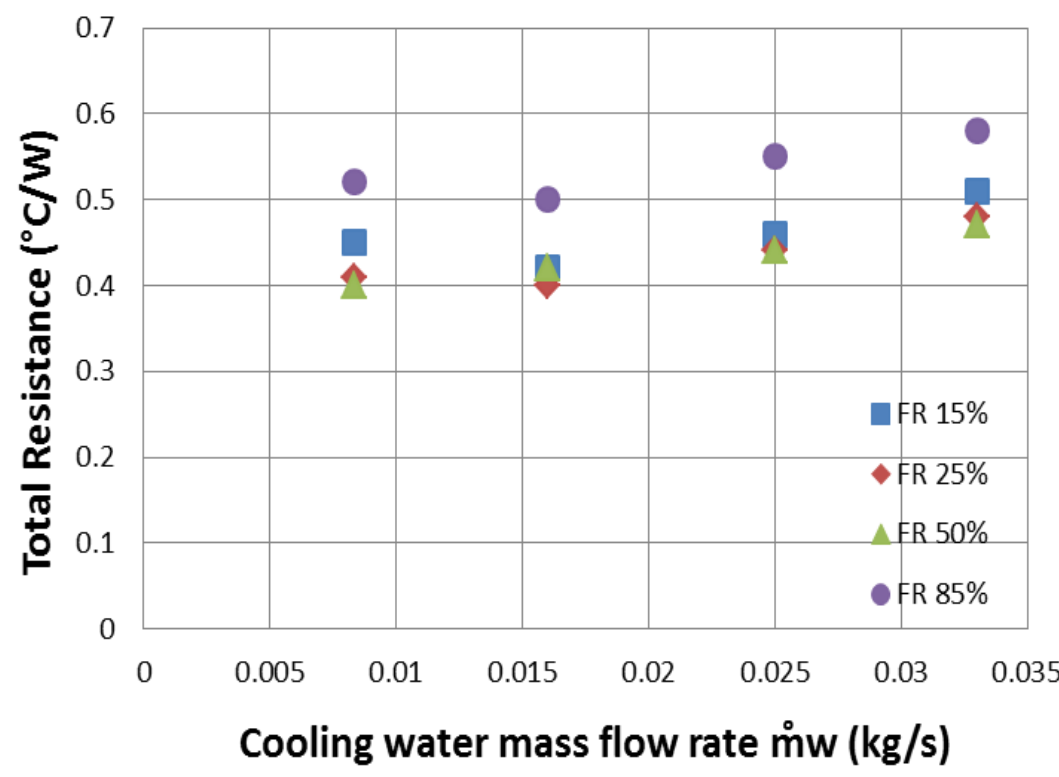

Figure (12) Experimental variation of measured total resistance with cooling water mass flow rate of SHP for input power $50 \mathrm{~W}$ at four fill ratios. 